\title{
The Regional Growth of Manufacturing: Markets, Wages, and Labor Composition
}

\author{
Neal E. Duffy*
}

\begin{abstract}
Changes in two important location factors, markets and labor, are investigated for convergence and their relationship to the regional growth of manufacturing. Analysis of the spatial composition of labor suggests that the Manufacturing Belt has experienced skilled-labor-augmenting technical progress to a greater extent than other regions, especially the Southeast. Though wage rates continue to diverge in the Manufacturing Belt, biased technical change and improvement in markets may help the region maintain a residual hegemony. However, the central states may also compete, possibly forming a new manufacturing belt in the U.S.
\end{abstract}

\section{INTRODUCTION}

The regional growth literature has generally concluded that proximity to markets and favorable labor climate are two of the most important determinants of manufacturing location (Moriarty 1992). ${ }^{1}$ Both surveys and econometric studies point to this conclusion, the best examples being the surveys of McLaughlin and Robock (1949) and Schmenner $(1978,1982)$, and Wheat's two econometric studies $(1973,1986)$. Schmenner's first survey, of company headquarters, was especially instructive, identifying "'proximity to markets' as the 'single most important' factor affecting the region and metropolitan/rural area choice. The only other consideration that approached the importance of market proximity was the concern for labor wage rates.... All other considerations were dwarfed by these two" (Schmenner 1982, p. 151) In Schmenner's (1982) second survey, the order was switched, but "favorable labor climate" and markets were cited by 76 percent and 55 percent of new manufacturing plants, respectively. Wheat (1986), after measuring the contribution of several location factors to $R^{2}$, found that markets alone accounted for 60 percent of the variation in state manufacturing employment growth from 1947 to 1977. Moriarty (1992) asserts that markets were more important than labor prior to the 1970 s, but that labor superseded markets as the primary location factor since then.

A variety of events throughout the 20th century contributed to market orientation; population movements, transportation improvements, and a greater complexity of inputs are the most frequently cited. On the other hand, firms with well-established, labor-intensive production processes, or a need for relatively low-skilled labor, gravitated toward areas with lower wages or more favorable labor climates. Though other factors, especially taxes, have been investigated thoroughly, the evidence for competing orientations still appears relatively thin. In the

"Department of Economics and Finance, State University of New York, College at Plattsburgh, Plattsburgh, NY. ${ }^{1}$ The locational determinants being discussed in this paper involve the region/state choice, rather than site selection in local areas, a distinction made by Schmenner (1982). 
choice of region or state (as opposed to competing local areas within a region) location studies seem to be in general agreement that education, taxes, energy prices, urbanization, et cetera, have been relatively insignificant.

The starting point for this study consisted of two more recent works. In the first, Duffy (1994) obtained location factors for 19 of 20 two-digit manufacturing industries $^{2}$ for the period 1954-1987. He found that markets were the strongest influence in 18 of those industries, with labor significant in 16 industries. Labor consistently ranked second to markets, and other factors were found to be much less important. The second study was an examination of both the causes of manufacturing's regional redistribution and the prospects for regional growth. However, in contrast to the first study, Crandall (1993) downplayed the importance of markets, stating: "the principal conclusion of this study is that the decline of manufacturing in the Rust Belt is due to labor market conditions: high wages and a bad industrial relations environment" (p. 103). He therefore saw little chance for an end to the movement of industry away from the Manufacturing Belt (his "Rust Belt"), even over the next few decades.

This study will show that the prospects for the Manufacturing Belt may be somewhat brighter than the assessment provided by Crandall (1993). Following up on the well-documented importance of markets and labor, it asks two questions: (1) How have market and labor conditions, including composition and wages, changed since 1954? and (2) What does that imply about future regional growth of manufacturing in the U.S. beyond the study period, i.e., beyond $1990^{3}$ ?

Since these are long-run questions, this study documents the evolution of markets and labor over a relatively long time frame, 1954 to 1990; it is also exploratory by nature, and more descriptive than inferential. As such, no advanced statistical techniques are employed, the only hypotheses being the trivial ones that a discernible pattern does, or does not, exist in observed variables. The units of observation are the lower 48 states, and because it bore the brunt of job losses, a primary focus is the traditional Manufacturing Belt. The rest of the country is divided into three broad geographic areas-Northwest, Southwest, and Southeastplus a "Transition Zone" linking those three areas to the Manufacturing Belt. ${ }^{4}$ Also, since previous research has demonstrated the importance of right-to-work laws as a labor factor in manufacturing location, the data and results are also viewed from the perspective of the right-to-work states, although they do not constitute any type of "region" in the traditional sense. All data were derived from common sources: the 1954 and 1972 Census of Manufactures, the 1990 Annual Survey of Manufactures, and Bureau of the Census Current Population Reports.

2Only SIC 21, Tobacco, was not included.

3Prior econometric studies, such as those mentioned, have utilized study periods ranging from 10 to 33 years. The end-of-period values (1990) for the variables in this study may lead to inferences that are relevant well into the 21st century, since they could be considered beginning-of-period values for growth studies beyond 1990.

${ }^{4}$ These regions were selected to be consistent with Duffy (1994), and were originally derived from Wheat (1986); they are defined in Tables 1,3, and 4. The Transition Zone should not be considered a region per se, but a statistical or geographical artifact. 
These three years had nearly identical civilian unemployment rates of 5.5 percent (1954), 5.6 percent (1972), and 5.5 percent (1990), so that data comparability problems were minimized.

\section{REGIONAL LABOR CHANGE: CONVERGENCE MINUS ONE?}

The dynamic behavior of regional wage levels has received a great deal of attention from both policy makers and regional economists. The conventional wisdom is that convergence took place throughout the 20th century, with the possible exception of the 1920s and 1980s (Nissan and Carter 1993; Barro and Sala-i-Martin 1992). ${ }^{5}$ Although there seems to be little dispute concerning an overall pattern of convergence, there remains some controversy over the reasons for that convergence. Neoclassicists such as Ohlin (1967) would argue that cheap labor attracted demand (i.e., industry) away from high-wage regions, thereby driving up wages, resulting in eventual convergence (Hansen 1994). Divergence, on the other hand, reflects an oversupply of labor in low-wage regions, or excess labor demand in high-wage regions, and may result from a lack of resource mobility, regional comparative advantages in industries having wage rates significantly higher or lower than average, or external economies (Myrdal's 1957 cumulative causation).

\section{Data Analysis of Wages}

Econometric studies have typically enlisted production wages, or in some cases right-to-work (RTW) dummy variables, in models of manufacturing location and growth. Since the composition of states having RTW laws has barely changed since their inception in 1947, the analysis of labor in this paper focuses only on wages, while making a special note of labor conditions in RTW and non-RTW states.

Table 1 shows average and indexed wages for production workers in current dollars for the lower 48 states, the five regions, and the RTW states. The current-dollar wage per man-hour, $\mathrm{W}_{\mathrm{c}}$, was found by dividing regional or state wages by total man-hours, and the resulting wage rates were then indexed to the U.S. average wage, $\mathrm{W}_{\mathrm{n}}$ :

$$
\begin{aligned}
& W_{c}=\text { (Total wages) / (Total man-hours), } \\
& W_{n}=(\text { Total wages, U.S.) / (Total man-hours, U.S.), } \\
& W_{i}=W_{c} / W_{n} .
\end{aligned}
$$

Values of $W_{i}$ that are less than 1 are below the average for the whole U.S., and values above 1 are above the U.S. average. As is evident from Table 1, the results seem to indicate a pattern of convergence for four of the five regions: the four regions outside the Manufacturing Belt each moved closer to the U.S. average (closer to $\mathrm{W}_{\mathrm{i}}=1.0$ ), while the Manufacturing Belt moved away from the average. The

${ }^{5}$ However, Deller, Shields, and Tomberlin (1996) have shown that the 1980s episode of divergence was reduced, if not eliminated, when prices were adjusted for regional differences. If true, then the alleged increase in wage inequality among all workers in the U.S. during the 1980s may also be less than previously thought to the extent that region-specific factors were a significant influence on incomes. Region-specific factors may include defense contracts, demography, industrial and occupational mix, and weather-related costs. See Beeson and Eberts (1989), Phillips (1992), and Carlino and Voith (1992). 
Southeast, which started out with the lowest wages, had the largest gains (10.8 percent), and all nine of its states experienced an increase in relative wages. Both of the western regions decreased after beginning the period significantly above average. But the Manufacturing Belt, which started out above average in 1954, saw increasing relative wages in 13 of 17 states and thus diverged from the U.S. average.

TABLE 1

Wage Rates for Production Workers, Current Dollar $\left(\mathrm{W}_{\mathrm{c}}\right)$, and Indexed $\left(\mathrm{W}_{\mathrm{i}}\right)$, by State and Region

\begin{tabular}{|c|c|c|c|c|c|c|c|c|c|}
\hline & \multicolumn{2}{|c|}{$\mathrm{W}_{\mathrm{c}}$} & \multicolumn{2}{|c|}{$\mathrm{W}_{\mathrm{i}}$} & & \multicolumn{2}{|c|}{$\mathrm{W}_{\mathrm{c}}$} & \multicolumn{2}{|c|}{$\mathrm{W}_{\mathrm{i}}$} \\
\hline & 1954 & 1990 & 1954 & 1990 & & 1954 & 1990 & 1954 & 1990 \\
\hline & \multicolumn{4}{|c|}{ Manufacturing Belt } & & \multicolumn{4}{|c|}{ Southeast } \\
\hline CT & 1.89 & 12.18 & 1.03 & 1.09 & ${ }^{*} \mathrm{AL}$ & 1.48 & 9.60 & .81 & .86 \\
\hline $\mathrm{DE}$ & 1.75 & 13.39 & .96 & 1.20 & *AR & 1.28 & 8.67 & .70 & .77 \\
\hline IL & 1.97 & 11.93 & 1.07 & 1.07 & ${ }^{*} \mathrm{FL}$ & 1.36 & 9.24 & .74 & .83 \\
\hline IN & 1.99 & 12.60 & 1.09 & 1.13 & ${ }^{*} \mathrm{GA}$ & 1.28 & 9.36 & .70 & .84 \\
\hline MA & 1.69 & 11.79 & .92 & 1.05 & ${ }^{*}$ LA & 1.62 & 11.97 & .88 & 1.07 \\
\hline MD & 1.76 & 12.31 & .96 & 1.10 & *MS & 1.20 & 9.42 & .66 & .75 \\
\hline ME & 1.44 & 10.79 & .78 & .96 & *NC & 1.27 & 8.90 & .70 & .80 \\
\hline MI & 2.21 & 14.72 & 1.21 & 1.32 & *SC & 1.29 & 9.42 & .70 & .84 \\
\hline $\mathrm{NH}$ & 1.75 & 11.36 & .81 & 1.02 & *TN & 1.46 & 9.57 & .80 & .86 \\
\hline NJ & 1.92 & 11.63 & 1.05 & 1.04 & & & & & \\
\hline NY & 1.84 & 11.33 & 1.00 & 1.01 & & \multicolumn{4}{|c|}{ Southwest } \\
\hline $\mathrm{OH}$ & 2.06 & 12.99 & 1.13 & 1.16 & *AZ & 1.93 & 11.01 & 1.05 & .98 \\
\hline PA & 1.83 & 11.29 & 1.00 & 1.01 & $\mathrm{CA}$ & 2.05 & 11.25 & 1.12 & 1.01 \\
\hline RI & 1.51 & 9.11 & .82 & .81 & $\mathrm{CO}$ & 1.80 & 11.66 & .98 & 1.04 \\
\hline WI & 1.90 & 11.50 & 1.03 & 1.03 & *KS & 1.98 & 11.35 & 1.08 & 1.01 \\
\hline WV & 1.91 & 12.44 & 1.04 & 1.11 & NM & 1.74 & 9.73 & .95 & .87 \\
\hline \multirow[t]{3}{*}{ VT } & 1.58 & 10.59 & .86 & .95 & *NV & 1.98 & 9.85 & 1.08 & .88 \\
\hline & & & & & OK & 1.72 & 11.24 & .94 & 1.01 \\
\hline & \multicolumn{4}{|c|}{ Transition Zone } & ${ }^{*} \mathrm{TX}$ & 1.73 & 11.05 & .95 & .99 \\
\hline *IA & 1.78 & 11.51 & .97 & 1.03 & *UT & 1.82 & 9.77 & .99 & .87 \\
\hline KY & 1.64 & 10.76 & .90 & .96 & & & & & \\
\hline MN & 1.84 & 11.19 & 1.00 & 1.00 & & \multicolumn{4}{|c|}{ Regions } \\
\hline MO & 1.77 & 11.08 & .96 & .99 & MB & 1.91 & 12.20 & 1.04 & 1.09 \\
\hline \multirow[t]{3}{*}{ *VA } & 1.46 & 10.46 & .80 & .93 & $\mathrm{TZ}$ & 1.69 & 10.94 & .93 & .98 \\
\hline & & & & & NW & 2.00 & 11.31 & 1.09 & 1.01 \\
\hline & & Nor & & & SE & 1.35 & 9.32 & .74 & .83 \\
\hline *ID & 1.85 & 10.40 & 1.01 & .93 & SW & 1.94 & 11.15 & 1.06 & 1.00 \\
\hline MT & 1.93 & 11.42 & 1.05 & 1.02 & & & & & \\
\hline *ND & 1.57 & 9.11 & .85 & .81 & & \multicolumn{4}{|c|}{ Right-to-Work } \\
\hline *NE & 1.68 & 10.14 & .92 & .91 & & 1.48 & 9.85 & .81 & .88 \\
\hline OR & 2.08 & 11.15 & 1.14 & 1.00 & & & & & \\
\hline *SD & 1.22 & 8.39 & .67 & .75 & & \multicolumn{4}{|c|}{ non-Right-to-Work } \\
\hline WA & 2.12 & 12.46 & 1.16 & 1.11 & & 1.92 & 11.90 & 1.05 & 1.06 \\
\hline \multirow[t]{3}{*}{ *WY } & 2.07 & 10.91 & 1.13 & .97 & & & & & \\
\hline & & & & & & \multicolumn{4}{|c|}{ United States } \\
\hline & & & & & & 1.83 & 11.19 & 1.00 & 1.00 \\
\hline
\end{tabular}

${ }^{*}$ Right-to-work state.

A two-way contingency table of the 48 states (Table $2 \mathrm{~d}$ ) and estimates of the coefficients of variation for each year support an overall pattern of convergence. In Table 2 the null hypothesis for the $\chi^{2}$ test is cell independence, which would indicate the presence of no correlation between the direction of change in state wage indices and their initial values. But the calculated $\chi^{2}$ statistic is a highly 
significant 16.3, rejecting the null hypothesis of cell independence. A declining coefficient of variation $(\sigma / \mu)$ in current dollar wages-15.2 percent in 1954 and 12.3 percent in 1990 for the 48 states-is also consistent with a leveling of wages during the time period. For just the five regions (using the regional averages), the coefficient of variation also decreased, from 13.4 percent in 1954 to only 8.5 percent in $1990 .^{6}$

\section{TABLE 2}

Contingency Tables of Changes in $\mathrm{W}_{\mathrm{i}}$ and $\mathrm{MKT}_{\mathrm{i}}, 1954-1990, \mathrm{~N}=48$

(a)

$\mathrm{MKT}_{\mathrm{i}}, 1954$

$<1.0>1.0$

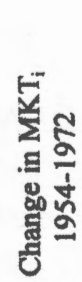

(c)

$\mathrm{MKT}_{\mathrm{i}}, 1954$

$<1.0 \quad>1.0$

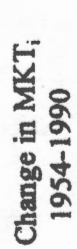

$<1.0 \quad>1.0$

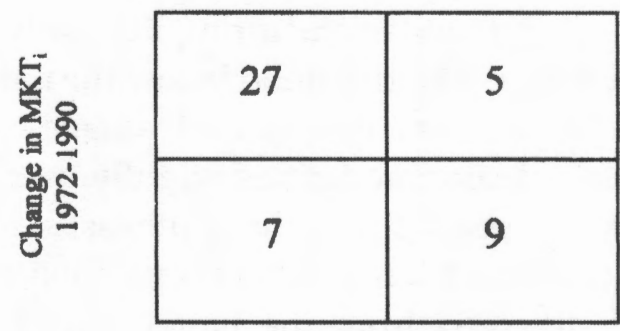

$x^{2}=8.52$

$\mathrm{p}=.0035$

$\mathrm{W}_{\mathrm{i}}, 1954$

$<1.0 \quad>1.0$
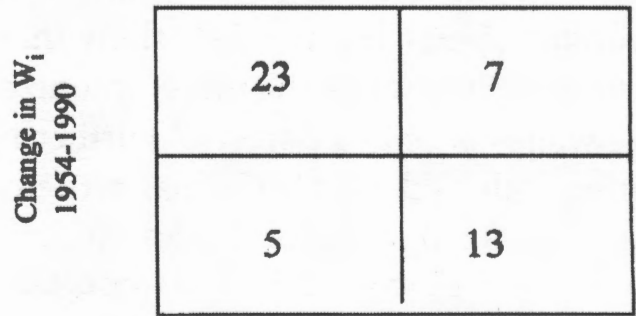

$$
\begin{aligned}
& x^{2}=16.30 \\
& p=.0001
\end{aligned}
$$

${ }^{6}$ Note that a declining coefficient of variation is, by definition, indicative of $\sigma$-convergence, while the $\chi^{2}$ test for independence is conceptually similar to $\beta$-convergence, as discussed by Eff (1999) and by Carlino and Mills (1996). In the actual test for $\beta$-convergence (regressing the growth rate of $W_{c}$ on its base value in 1954) the $t-$ statistic for $\beta$ was -5.95 , which was significant at the .0001 level $(\mathrm{N}=48)$. 
The implication of Table 2d, and acceptance of the (alternative) hypothesis of convergence, is that a regional wage advantage or disadvantage can generally be thought of as short-run in nature. What may be a comparative advantage (in labor) today, quite possibly may be a comparative disadvantage in, say, 30 or 40 years. For example, Table 1 shows that the West actually reversed its standing relative to the Manufacturing Belt over the period. By 1990, the Manufacturing Belt was about 8 to 9 percent above the western regions, despite starting out in 1954 significantly lower than the West. This "western reversal" was quite pervasive, with only 4 of the 17 western states experiencing a relative wage increase: South Dakota (+12.4 percent), Oklahoma (+6.7 percent), Colorado (+6.0 percent), and Texas (+4.3 percent). On the other hand, Nevada (-18.4 percent), Wyoming (-13.5 percent), Oregon (-12.4 percent), Utah (-12.2 percent), and California (-10.2 percent) had the largest decreases of the 48 states.

In the Manufacturing Belt, only three peripheral states-Vermont, Maine, and Rhode Island-stood below the national average by 1990 . However, the Manufacturing Belt's wage disadvantage compared to the Southeast and other RTW states actually moderated slightly over the period: in 1954 its average wage rate was 41 percent above the Southeast's, and by 1990 it declined to 31 percent above the Southeast's. In summation, although the data indicate that the Manufacturing Belt diverged from the national average, the "southern moderation" and the "western reversal" are both consistent with convergence and an underlying process of long-run equilibrium adjustment. ${ }^{7}$ Although it is beyond the scope of this article to fully document the causes for convergence (or, in the case of the Manufacturing Belt, divergence), economic theory would suggest that it has something to do with labor productivity. Bernard and Jones (1996) did indeed find that regional labor productivity of manufacturing converged from 1963 to 1989.

Finally, one other observation deserves emphasis: wage changes in moreunionized, non-RTW states were not as great as changes in less-unionized, RTW states. This is important to note since unionization, and the resulting "bad" industrial relations environment it usually conjures up, are often painted as protagonists in the demise of the Manufacturing Belt, especially, as noted above, by Crandall (1993). But the data show that the relative wage in RTW states increased by 8.6 percent, while the more-unionized, non-RTW states had an increase in average wages of only 1 percent. ${ }^{8}$ Furthermore, non-RTW states outside the Manufacturing Belt, led by California, actually experienced declining wages, while the less-unionized states of the Southeast had the largest percentage increase of any region, 10.8 percent. It is also important to recognize that every state in the Southeast had a RTW law, and therefore weaker unions, while every state in the Manufacturing Belt did not have a RTW law, and therefore stronger unions. Eliminating

${ }^{7}$ Note that Eff (1999), using a decomposition technique applied to county income data, found that manufacturing wages experienced divergence from 1969 to 1996, yet he also concluded that "manufacturing...promoted convergence [of income]" (p. 26). Also, while there is no formal attempt at investigating the presence of equilibrium, the interested reader may consult Levy (1988), Bartik (1988), and Herzog and Schlottmann (1984) for further discussions of regional equilibrium and disequilibrium.

${ }^{8}$ Calculated similarly to $W_{c}$ and $W_{n}$. 
such embedded regional variations in unionization by excluding the Manufacturing Belt and the Southeast, by 1990 there existed a wage gap between the remaining RTW (\$10.82) and non-RTW (\$11.28) states of only 4.3 percent. $^{9}$

\section{THE SPATIAL DIVISION OF LABOR}

The composition of labor has attracted much attention in recent years because of its connection to income distribution, education policy, labor markets, trade, and economic growth. Overall, macro-empirical studies have found technical change in manufacturing to be skilled-labor augmenting or, equivalently, production-labor saving (Berman, Bound, and Griliches 1994; Rigby 1992, Sachs and Shatz 1994). Prima facie evidence is the steep decline in the ratio of production to nonproduction jobs: 4 to 1 in 1954, declining to about 3 to 2 at present. Moreover, empirical research has supported the capital-skill and technology-skill complementarity hypothesis (Goldin and Katz 1998). Regional economists have also studied labor composition, usually in the context of regional growth, income distribution (Williamson 1965), or the product cycle (Hansen 1988; Moriarty 1992, 1983).

An investigation of changes in labor composition is integral to a more complete assessment of regional growth of manufacturing. Since the preceding analysis suggested a general process of wage convergence in production (notwithstanding the Manufacturing Belt), we may anticipate movement towards uniformity in the spatial division of labor as well. This may not be the case, however, if regions follow distinct trajectories of technological change because of some underlying comparative advantage. Rigby and Essletzbichler (1997) show that regional differences in production techniques tend to persist through time, as suggested long ago by Myrdal's (1957) cumulative causation model. Riefler (1995), Bartik (1988), and de Bartolome and Spiegel (1997) also raise the possibility that economic development can be skewed in one direction or another by state developmental agencies. Many states have tried to raise their skill pool by increasing educational standards, providing capital subsidies, or promoting "high-tech" growth.

At one time, early in the development of regional science, there was a vigorous debate concerning the validity of classifying nonproduction workers as "manufacturing" employment. Should studies of manufacturing growth utilize just production workers, or the total employment in manufacturing, including nonproduction workers? The issue was finally resolved in a published exchange among Craig, Netzer, and Thompson (1959) and Fuchs (1959), in which they almost unanimously settled on using total employment. ${ }^{10}$ Thereafter, almost all regional growth studies of manufacturing used total employment, rather than production workers. More recently, however, the subject of labor heterogeneity has resurfaced, partly because of the issues mentioned above, and partly because

\footnotetext{
${ }^{9}$ However, Schmenner (1982) has shown that employers are often just as concerned with narrow job descriptions, work rules, seniority restrictions, etc., as with higher wage rates, so that the deterrent effect of unions probably extends beyond the mere influence of unionization on relative wage scales.

${ }^{10}$ It may be time to reopen this debate since nonproduction employment is today nearing 40 percent of total manufacturing employment. At the time of their debate, the percentage was closer to 20 percent.
} 
skilled workers are increasingly being perceived as making significant contributions to overall manufacturing productivity (Hansen 1994).

A useful model often mentioned in connection with labor heterogeneity is the product cycle. As others have noted (Hansen 1988; Moriarty 1983, 1992; Norton and Rees 1979; Vernon 1966) it provides a framework for linking the firm's goal of profit maximization with the observed spatial division of labor. The product cycle predicts that low-cost regions have comparative advantages in attracting routine, standardized, production activities said to dominate the later stages of a product's life cycle. Such locations can include less-developed rural areas, smaller cities in the urban hierarchy, or low-wage foreign countries (LDCs). The product cycle is assumed to become more of a factor in determining plant location when firms produce a wide array of products or are interested in establishing branch plants. To either extent, it predicts that locations having lower wages or more favorable labor climates will have greater concentrations of unskilled labor.

\section{Data Analysis of Labor Composition}

Table 3 shows state production workers as a percentage of total manufacturing employment for 1954 and 1990 indexed to the national average for each year. Indexing is required because of the aforementioned dramatic decrease in $\mathrm{PWP}_{\mathrm{n}}$ from 1954 to 1990:

(4) $\mathrm{PWP}_{\mathrm{s}}=$ (Production workers, state) / (Total MFG employment, state),

(5) $\mathrm{PWP}_{\mathrm{n}}=($ Production workers, U.S.) / (Total MFG employment, U.S.),

(6) $\quad \mathrm{PWP}_{\mathrm{i}}=\mathrm{PWP}_{\mathrm{s}} / \mathrm{PWP}_{\mathrm{n}}$.

The usefulness of the production worker index is that it provides a rough measure of a state or region's amount of "skilled" labor in manufacturing. As in many other studies-for example, Sachs and Shatz (1994), Lawrence and Slaughter (1993), and Berman, Bound, and Griliches (1994)—production labor is considered here to be "unskilled," while nonproduction labor is "skilled." Although this oversimplification is required by the lack of further detail in the Commerce data, there is some empirical support: Berman, Bound, and Griliches (1994) found that education levels, computer usage, and research-development expenditures were all highly correlated with the usage of nonproduction labor. Also, Goldin and Katz (1998, p. 719) claim that: "A larger nonproduction worker share of employment is likely to be associated with an increase in the average amount of skill required of all workers, both because white-collar jobs tend to have higher education requirements and because technical nonproduction workers (engineers and chemists) tend to work with more-educated production workers." 
TABLE 3

Indexed Production Worker Shares $\left(\mathrm{PWP}_{\mathrm{i}}\right)$ of Total Employment, by State and Region

\begin{tabular}{|c|c|c|c|c|c|c|c|}
\hline & 1954 & 1972 & 1990 & & 1954 & 1972 & 1990 \\
\hline \multicolumn{5}{|c|}{ Manufacturing Belt } & \multicolumn{3}{|c|}{ Southeast } \\
\hline CT & 1.00 & 0.91 & 0.83 & *AR & 1.09 & 1.17 & 1.22 \\
\hline $\mathrm{DE}$ & 1.00 & 0.77 & 0.71 & ${ }^{*} \mathrm{AL}$ & 1.10 & 1.14 & 1.20 \\
\hline IL & 0.97 & 0.97 & 0.96 & ${ }^{*} \mathrm{FL}$ & 1.00 & 0.99 & 0.95 \\
\hline IN & 0.99 & 1.05 & 1.11 & *GA & 1.09 & 1.11 & 1.11 \\
\hline MA & 1.00 & 0.95 & 0.88 & ${ }^{*}$ LA & 1.00 & 1.05 & 1.11 \\
\hline MD & 0.98 & 0.97 & 0.90 & ${ }^{*} \mathrm{MS}$ & 1.11 & 1.17 & 1.25 \\
\hline ME & 1.11 & 1.16 & 1.14 & ${ }^{*} \mathrm{NC}$ & 1.12 & 1.14 & 1.16 \\
\hline MI & 1.02 & 1.00 & 1.00 & ${ }^{*} \mathrm{SC}$ & 1.10 & 1.15 & 1.17 \\
\hline $\mathrm{NH}$ & 1.08 & 1.06 & 0.98 & *TN & 1.04 & 1.10 & 1.14 \\
\hline NJ & 0.97 & 0.92 & 0.84 & & & & \\
\hline NY & 0.98 & 0.90 & 0.89 & & \multicolumn{3}{|c|}{ Southwest } \\
\hline $\mathrm{OH}$ & 0.98 & 0.98 & 1.02 & ${ }^{*} \mathrm{AZ}$ & 0.99 & 0.93 & 0.84 \\
\hline PA & 1.01 & 1.01 & 1.02 & $\mathrm{CA}$ & 0.95 & 0.93 & 0.91 \\
\hline RI & 1.06 & 1.09 & 1.03 & $\mathrm{CO}$ & 0.96 & 0.94 & 0.90 \\
\hline VT & 1.05 & 0.99 & 1.02 & ${ }^{*} \mathrm{KS}$ & 0.95 & 1.04 & 1.05 \\
\hline WI & 0.98 & 1.01 & 1.05 & ${ }^{*} \mathrm{NV}$ & 0.98 & 0.97 & 1.02 \\
\hline WV & 1.03 & 1.08 & 1.12 & NM & 0.79 & 1.03 & 1.08 \\
\hline \multirow{2}{*}{\multicolumn{4}{|c|}{ Transition Zone }} & OK & 0.96 & 0.94 & 1.01 \\
\hline & & & & ${ }^{*} \mathrm{TX}$ & 0.97 & 0.99 & 0.96 \\
\hline *IA & 0.95 & 1.02 & 1.07 & *UT & 0.99 & 0.96 & 0.98 \\
\hline KY & 1.03 & 1.09 & 1.17 & & & & \\
\hline $\mathrm{MN}$ & 0.94 & 0.91 & 0.89 & & \multicolumn{3}{|c|}{ Regions } \\
\hline MO & 0.98 & 0.97 & 0.98 & MB & 0.99 & 0.97 & 0.97 \\
\hline \multirow[t]{3}{*}{ *VA } & 1.07 & 1.10 & 1.11 & $\mathrm{TZ}$ & 1.00 & 1.02 & 1.03 \\
\hline & & & & NW & 1.01 & 1.05 & 1.01 \\
\hline & & orthwe & & SE & 1.08 & 1.12 & 1.13 \\
\hline *ID & 1.07 & 1.12 & 1.15 & SW & 0.95 & 0.95 & 0.93 \\
\hline MT & 1.03 & 1.12 & 1.01 & & & & \\
\hline *NE & 0.96 & 1.05 & 1.11 & & \multicolumn{3}{|c|}{ Right-to-Work } \\
\hline *ND & 0.88 & 0.98 & 1.03 & & 1.04 & 1.08 & 1.09 \\
\hline OR & 1.08 & 1.11 & 1.10 & & & & \\
\hline *SD & 0.88 & 1.04 & 1.15 & & \multicolumn{3}{|c|}{ non-Right-to-Work } \\
\hline WA & 0.98 & 0.99 & 0.90 & & .99 & .97 & .96 \\
\hline *WY & 0.94 & 1.02 & 1.04 & & & & \\
\hline
\end{tabular}

*Right-to-work state.

Table 3 provides us with several observations worth noting:

(1) The PWP ${ }_{i}$ either increased or decreased monotonically in 37 of the 48 states, so that whatever trend occurred from 1954 to 1972, also tended to occur from 1972 to 1990 . For example, Arkansas (AR) went from being 9 percent above the U.S. average in $1954\left(\mathrm{PWP}_{\mathrm{i}}=1.09\right)$, to 17 percent above average in $1972\left(\mathrm{PWP}_{\mathrm{i}}=1.17\right)$, to 22 percent above average by $1990\left(\mathrm{PWP}_{\mathrm{i}}=1.22\right)$. This suggests that the underlying factors responsible for changes in production orientation were fairly consistent throughout the period, and it supports Rigby and Essletzbichler's (1997) finding that regions tend to maintain unique paths of economic development. 
(2) In the 17 states comprising the Manufacturing Belt, the $\mathrm{PWP}_{\mathrm{i}}$ increased in only six states between 1954 and $1990 .^{11}$

(3) In the 21 RTW states, the PWP ${ }_{i}$ increased from 1954 to 1990 in all but four states, and by 1990, there were 16 states with values greater than or equal to 1 .

(4) Five of the seven states with the largest increases in the PWP ${ }_{i}$ were RTW states:

New Mexico

*S. Dakota

*Mississippi

*Nebraska

*N. Dakota

Kentucky

*Arkansas

*RTW state

Though New Mexico is not an RTW state, its wages were the lowest of any western state, including Texas, an RTW state.

(5) All but two of the states with the largest decreases in the $\mathrm{PWP}_{\mathrm{i}}$ were in the Manufacturing Belt:

$\begin{array}{ll}\text { *Delaware } & (-.31) \\ \text { *Connecticut } & (-.19) \\ \text { Arizona } & (-.16) \\ \text { *New Jersey } & (-.15) \\ \text { *Massachusetts } & (-.14) \\ \text { *New Hampshire } & (-.13) \\ \text { *New York } & (-.12) \\ \text { Washington } & (-.11) \\ \text { *Maryland } & (-.10)\end{array}$

*Manufacturing Belt state

Arizona and Washington, however, are special cases. They each have dominant cities (Phoenix, Seattle) that have attracted company headquarters and the many tertiary activities usually associated with large

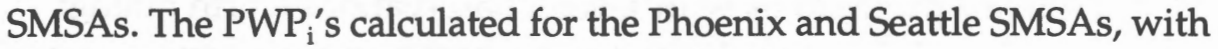
values of .85 and .83 , respectively, confirm this.

(6)The coefficient of variation $(\sigma / \mu)$ calculated for the state $\mathrm{PWP}_{\mathrm{i}}$ 's increased from 6.5 percent in 1954 to 11.4 percent in 1990, indicating an increasing polarization of states in relation to production.

Overall, the results do appear to be consistent with product cycle theory in that production has obviously shown a tendency to gravitate towards low-wage and RTW locations. By 1990, lower-wage RTW states were 12.2 percent above the Manufacturing Belt in percent production workers, compared to only 4.8 percent above in 1954. Even outside the Manufacturing Belt and the Southeast, RTW states were 1.6 percent above non-RTW states in 1954, rising to 7.2 percent above by 1990. Further analysis shows that from 1954 to 1990 the $\mathrm{PWP}_{\mathrm{i}}$ experienced increasing

${ }^{11}$ There is no inherent meaning to the value of $\mathrm{PWP}_{\mathrm{i}}$ being less than (or greater than) unity, only that it shows there is a relatively low (or high) percentage of production workers. 
negative correlation with production wages $(-.40,-.55)$, and increasing positive correlation with RTW status $(.07, .41)$. The larger change in correlation with RTW lends some support to Schmenner's (1982) finding that firms tend to be much more wary of union rules and restrictions than of higher wage rates.

The declining value of the $\mathrm{PWP}_{\mathrm{i}}$ over the period shows that despite an approximate loss of 2 million manufacturing jobs, the Manufacturing Belt appears to have become something of a magnet for non-production-intensive manufacturing. ${ }^{12}$ While Crandall's (1993) contention may have been correct (that greater wage rates and more restrictive labor practices drove away some manufacturers), the effect seems to have been greater on production than nonproduction workers. But this restructuring can also be viewed in a more positive light to the extent that the increase in nonproduction labor signifies greater research and development, the substitution of capital for process labor (robotics), or increased staff operations (headquarters). To characterize the existing higher wage rates in the Manufacturing Belt as a temporary disequilibrium or a deterrent to manufacturing growth may be unreasonable; they may be portrayed instead as a direct consequence of greater capital-labor ratios and the positive impact of skilled labor on productivity (Blackley 1986; Hansen 1994). ${ }^{13}$ Other possibilities include a greater valuation of output or an industrial structure favoring high-wage industries. Whatever the reason, structural differences within the Manufacturing Belt appear to be thwarting its wage convergence with the rest of the U.S.

\section{MARKETS: HOPE FOR THE MANUFACTURING BELT?}

Previous research has recognized the importance of markets to manufacturing location, but little effort has been made to assess their dynamic behavior, or the impact they may have on future growth. Chinitz and Vernon (1960) noticed that regional convergence of markets had been occurring since at least 1899 . Their measure of markets was simply the ratio of population to employment $(\mathrm{P} / \mathrm{E})$, a common demand/supply formulation used in both theoretical (Krugman 1991) and empirical (Duffy 1994, Wheat 1986) work since then. Others have made the related observation that $\mathrm{P} / \mathrm{E}^{\prime}$ s reciprocal, $\mathrm{E} / \mathrm{P}$, has fallen in the Manufacturing Belt (Norton and Rees 1979) or has converged across regions (Norton 1986), but have not made a strong connection to markets or the growth potential of regions.

Though many studies have relied on P/E to estimate market potential, the measure does suffer to some extent from simplicity. Ideally, one should survey individual industries within a region, determine unique market areas, and then sum the demands for all industrial outputs to estimate aggregate potential demand for manufactures. However, the measurement of markets depends on both supply and demand, implying that supply areas must be similarly measured. Unfortunately, doing so creates an unwieldy, nebulous, and quite possibly disjointed set of demand and supply areas for each industry. The way out of this conundrum ${ }^{12}$ Chinitz (1986), Moriarty (1992, 1983), Caves et al. (1993), and Connaughton and Madsen (1990) have also studied these shifts.

${ }^{13}$ For another point of view see Goldfarb, Yezer, and Crewe (1983), who suggested that persistent wage differences are indicative of disequilibrium and are due to inadequate information transfer between regions. 
is that in area (as opposed to industry) studies, one is usually interested in fixed boundaries, so that consistent, though often arbitrary, geographic limits are required for the location of both potential supply and demand. This is the justification for the often-criticized procedure of confining supply and demand to fixed areas, such as states or Census regions. ${ }^{14}$

\section{Data Analysis of Markets}

Previous studies have enlisted income, population, or, occasionally, population density as a proxy for market demand,$^{15}$ and production or employment in the industry as a proxy for market supply. In this study, the potential strength of the market for manufacturing within states, $\mathrm{MKT}_{s}$, is similarly estimated by the ratio of demand to supply within states, using population as the proxy for demand and total manufacturing employment as the proxy for supply: ${ }^{16}$

$$
\mathrm{MKT}_{\mathrm{s}}=\mathrm{P}_{\mathrm{s}} / \mathrm{E}_{\mathrm{s}} \text {, }
$$

where

$$
\begin{aligned}
& P_{s}=\text { Population of state } \\
& E_{s}=\text { Manufacturing employment in state. }
\end{aligned}
$$

The state values for $\mathrm{MKT}_{\mathrm{s}}$ are then indexed to the national values for each year, resulting in an indexed measure of markets for each state, $\mathrm{MKT}_{\mathrm{i}}$ :

$$
\begin{aligned}
& \mathrm{MKT}_{\mathrm{n}}=\mathrm{P}_{\mathrm{n}} / \mathrm{E}_{\mathrm{n}}, \\
& \mathrm{MKT}_{\mathrm{i}}=\mathrm{MKT}_{\mathrm{s}} / \mathrm{MKT}_{\mathrm{n}},
\end{aligned}
$$

where

$$
\begin{aligned}
& P_{n}=\text { U.S. population, } \\
& E_{n}=\text { U.S. manufacturing employment. }
\end{aligned}
$$

Values of $\mathrm{MKT}_{\mathrm{i}}$ greater than 1 indicate that a state has a relatively strong market for manufactures; the region is relatively undersupplied and therefore must import manufactured goods. Values less than 1 indicate a relatively oversupplied market. "Oversupply" refers merely to the fact that employment, and therefore production, are relatively high compared to population, producing a low $\mathrm{P} / \mathrm{E}$. However, oversupply is not synonymous with overconsumption; areas with low $\mathrm{P} / \mathrm{E}$ values presumably produce enough to satisfy local consumption, and then export the rest of their goods to other regions. Though $\mathrm{P} / \mathrm{E}$ has its limitations, it

${ }^{14}$ The alternative alluded to is the gravity-type model, which should be, but seldom is, applied to both supply and demand measurement in order to be consistent. The use of fixed-boundary $P / E$ values in this and other studies suffers from virtually the same kind of limitations imposed by shift-share analysis, which also employs what may be considered questionable assumptions.

15 Of course many, if not most, manufacturing industries sell to other manufacturing industries rather than to end users, implying that it is inadequate to use resident, i.e., consumer, population or income to approximate demand. However, in earlier (unpublished) research I estimated and tested intermediate demand at the twodigit level using I/O tables to account for interindustry linkages. Besides the questionable procedure of applying national I/O tables to states, it was a rather fruitless exercise; first because of data restrictions, and second because the variable that was constructed invariably did not perform well, in contrast to the simple formulation used here and in many previous studies. Population thus serves as a proxy for both intermediate and final demand.

${ }_{16}$ As a proxy for demand, both Duffy $(1994)$ and Wheat $(1986,1973)$ found that population and income produced nearly the same results. 
has been shown to perform quite well in explaining the growth of manufacturing for various time periods and levels of aggregation. Areas with strong markets, as measured at the beginning of a period, have historically grown faster than areas with weaker markets. ${ }^{17}$

Table 4 shows indexed values of $\mathrm{MKT}_{\mathrm{i}}$ for 1954, 1972, and 1990. Since changes in the index occur only because of changes in $\mathrm{P}_{\mathrm{s}}$ or $\mathrm{E}_{\mathrm{s}}$ the table also shows the percentage changes in $P_{s}$ and $E_{s}$ for the two subperiods 1954-1972 and 19721990 , indexed to the percentage change in U.S. population $\left(P_{n}\right)$ and employment $\left(E_{n}\right)$ for the same two periods:

(10) $\quad P_{i}=\left(\%\right.$ change in $\left.P_{s}\right) /\left(\%\right.$ change in $\left.P_{n}\right)$,

(11) $\quad E_{i}=\left(\%\right.$ change in $\left.E_{s}\right) /\left(\%\right.$ change in $\left.E_{n}\right)$.

TABLE 4

Indexed Values for Markets $\left(\mathrm{MKT}_{\mathrm{i}}\right)$, Population Change $\left(\mathrm{P}_{\mathrm{i}}\right)$, and Employment Change $\left(\mathrm{E}_{\mathrm{i}}\right)$, by State and Region

\begin{tabular}{|c|c|c|c|c|c|c|c|}
\hline & \multicolumn{3}{|c|}{$\mathrm{MKT}_{\mathrm{i}}$} & \multicolumn{2}{|c|}{$P_{i}$} & \multicolumn{2}{|c|}{$E_{i}$} \\
\hline & 1954 & 1972 & 1990 & $1954-72$ & $1972-90$ & $1954-72$ & $1972-90$ \\
\hline \multicolumn{8}{|c|}{ Manufacturing Belt } \\
\hline CT & 0.27 & 0.46 & 0.57 & 1.27 & 0.30 & -0.07 & -0.77 \\
\hline $\mathrm{DE}$ & 0.48 & 0.49 & 0.60 & 1.80 & 0.74 & 1.62 & -0.27 \\
\hline IL & 0.39 & 0.51 & 0.68 & 0.76 & 0.07 & .23 & -1.30 \\
\hline IN & 0.37 & 0.45 & 0.54 & 0.77 & 0.22 & 0.44 & -0.71 \\
\hline MA & 0.36 & 0.56 & 0.68 & 0.62 & 0.17 & -0.18 & -0.82 \\
\hline MD & 0.53 & 0.94 & 1.34 & 1.71 & 0.80 & 0.02 & -0.97 \\
\hline ME & 0.45 & 0.61 & 0.71 & 0.38 & 0.87 & -0.09 & 0.20 \\
\hline MI & 0.36 & 0.50 & 0.61 & 0.90 & 0.14 & 0.16 & -0.86 \\
\hline NH & 0.37 & 0.51 & 0.72 & 1.28 & 1.92 & 0.35 & 0.16 \\
\hline NJ & 0.34 & 0.52 & 0.73 & 1.29 & 0.23 & 0.13 & -1.42 \\
\hline NY & 0.42 & 0.65 & 0.93 & 0.52 & -0.09 & -0.24 & -1.79 \\
\hline $\mathrm{OH}$ & 0.36 & 0.47 & 0.60 & 0.63 & 0.05 & 0.13 & -1.10 \\
\hline PA & 0.39 & 0.50 & 0.70 & 0.33 & -0.01 & -0.01 & -1.63 \\
\hline RI & 0.33 & 0.49 & 0.59 & 0.60 & 0.16 & -0.10 & -0.82 \\
\hline VT & 0.53 & 0.74 & 0.76 & 0.73 & 0.99 & 0.05 & 1.09 \\
\hline WI & 0.42 & 0.54 & 0.53 & 0.83 & 0.36 & 0.34 & 0.54 \\
\hline WV & 0.82 & 0.89 & 1.30 & -0.22 & -0.00 & 0.03 & -1.82 \\
\hline \multicolumn{8}{|c|}{ Transition Zone } \\
\hline IA & .82 & 0.80 & 0.72 & 0.31 & -0.16 & 0.68 & 0.39 \\
\hline KY & 1.01 & 0.76 & 0.79 & 0.44 & 0.51 & 1.62 & 0.44 \\
\hline $\mathrm{MN}$ & 0.78 & 0.76 & 0.66 & 0.77 & 0.57 & 1.03 & 1.74 \\
\hline MO & 0.57 & 0.65 & 0.72 & 0.47 & 0.34 & 0.38 & -0.15 \\
\hline VA & 0.74 & 0.76 & 0.87 & 1.18 & 1.32 & 1.19 & 0.72 \\
\hline \multicolumn{8}{|c|}{ Northwest } \\
\hline ID & 1.25 & 1.05 & 0.98 & 0.91 & 1.48 & 1.66 & 2.37 \\
\hline MT & 1.73 & 1.99 & 2.38 & 0.54 & 0.51 & 0.40 & -0.37 \\
\hline NE & 1.18 & 1.07 & 0.95 & 0.48 & 0.14 & 1.03 & 0.96 \\
\hline ND & 4.65 & 3.70 & 2.33 & 0.57 & 0.03 & 1.73 & 3.40 \\
\hline OR & 0.63 & 0.73 & 0.78 & 1.04 & 1.33 & 0.70 & 1.19 \\
\hline SD & 2.80 & 2.33 & 1.39 & 0.09 & 0.10 & 0.95 & 4.02 \\
\hline WA & 0.67 & 0.90 & 0.79 & 1.11 & 1.88 & 0.37 & 3.55 \\
\hline WY & 2.46 & 2.95 & 2.65 & 0.49 & 1.38 & 0.27 & 2.60 \\
\hline
\end{tabular}

17In a previous study, Duffy (1994) found that in two-digit SICs various forms of this type of market variable usually explained 30 to 50 percent of state employment growth in manufacturing. 
TABLE 4 (continued)

Indexed Values for Markets $\left(\mathrm{MKT}_{\mathrm{i}}\right)$, Population Change $\left(\mathrm{P}_{\mathrm{i}}\right)$, and Employment Change $\left(\mathrm{E}_{\mathrm{i}}\right)$, by State and Region

\begin{tabular}{|c|c|c|c|c|c|c|c|}
\hline & \multicolumn{3}{|c|}{$\mathrm{MKT}_{\mathrm{i}}$} & \multicolumn{2}{|c|}{$P_{i}$} & \multicolumn{2}{|c|}{$E_{i}$} \\
\hline & 1954 & 1972 & 1990 & $1954-72$ & $1972-90$ & 1954-72 & $1972-90$ \\
\hline \multicolumn{8}{|c|}{ Southeast } \\
\hline AR & 1.16 & 0.66 & 0.64 & 0.41 & 0.76 & 2.77 & 1.20 \\
\hline AL & 0.71 & 0.65 & 0.65 & 0.50 & 0.65 & 1.02 & 0.80 \\
\hline FL & 1.43 & 1.28 & 1.55 & 3.61 & 3.37 & 3.76 & 2.57 \\
\hline GA & 0.62 & 0.60 & 0.68 & 0.95 & 1.63 & 1.16 & 1.18 \\
\hline LA & 1.01 & 1.24 & 1.47 & 0.95 & 0.57 & 0.50 & -0.26 \\
\hline MS & 1.16 & 0.67 & 0.66 & 0.27 & 0.62 & 2.53 & 0.94 \\
\hline NC & 0.49 & 0.42 & 0.47 & 0.80 & 1.19 & 1.53 & 0.67 \\
\hline SC & 0.52 & 0.46 & 0.57 & 0.65 & 1.32 & 1.21 & 0.36 \\
\hline TN & 0.65 & 0.52 & 0.58 & 0.68 & 0.87 & 1.66 & 0.44 \\
\hline \multicolumn{8}{|c|}{ Southwest } \\
\hline $\mathrm{AZ}$ & 1.82 & 1.25 & 1.21 & 3.56 & 3.84 & 5.49 & 5.26 \\
\hline CA & 0.63 & 0.79 & 0.84 & 1.94 & 2.03 & 1.06 & 2.06 \\
\hline $\mathrm{CO}$ & 1.22 & 1.06 & 1.09 & 1.79 & 1.74 & 2.32 & 2.03 \\
\hline KS & 0.79 & 0.99 & 0.77 & 0.38 & 0.41 & 0.10 & 2.24 \\
\hline NV & 1.91 & 3.18 & 2.79 & 4.76 & 5.55 & 1.58 & 8.86 \\
\hline NM & 2.65 & 2.72 & 2.26 & 1.20 & 1.81 & 1.20 & 3.92 \\
\hline OK & 1.37 & 1.10 & 1.12 & 0.71 & 0.86 & 1.65 & 0.99 \\
\hline TX & 1.05 & 0.94 & 1.07 & 1.20 & 2.05 & 1.67 & 1.60 \\
\hline UT & 1.33 & 1.19 & 1.01 & 1.54 & 2.34 & 1.20 & 4.51 \\
\hline \multicolumn{8}{|c|}{ Regions* } \\
\hline MB & 0.53 & 0.70 & 0.85 & 0.74 & 0.12 & 0.07 & -1.22 \\
\hline $\mathrm{TZ}$ & 1.01 & 0.95 & 0.92 & 0.68 & 0.54 & 1.00 & 0.61 \\
\hline NW & 1.29 & 1.34 & 1.14 & 0.81 & 1.07 & 0.73 & 2.38 \\
\hline SE & 1.00 & 0.85 & 0.92 & 1.11 & 1.40 & 1.75 & 0.98 \\
\hline SW & 1.16 & 1.18 & 1.17 & 1.66 & 1.86 & 1.45 & 2.26 \\
\hline \multicolumn{8}{|c|}{ Right-to-Work** } \\
\hline & 1.59 & 1.18 & 1.09 & $32.8 \%$ & $34.5 \%$ & $69.3 \%$ & $20.5 \%$ \\
\hline \multicolumn{8}{|c|}{ non-Right-to-Work } \\
\hline & .86 & .93 & .96 & $26.9 \%$ & $12.6 \%$ & $10.1 \%$ & $-8.7 \%$ \\
\hline
\end{tabular}

*The base values for $\mathrm{MKT}_{\mathrm{i}}, \mathrm{P}_{\mathrm{i}}$, and $\mathrm{E}_{\mathrm{i}}$ were the average $\mathrm{P} / \mathrm{E}$, population change, and employment change for the five regions $(\mathrm{N}=5)$.

**For the right-to-work and non-right-to-work states, the values for $\mathrm{MKT}_{\mathrm{i}}$ were indexed to the U.S. values for $\mathrm{P} / \mathrm{E}$ in each year. The last four columns are actual, non-indexed percentage changes for population and total employment.

In order to assess the prospects for future regional growth, it is instructive to examine long-run changes in the market index from 1954 to 1990. Table 4 indicates that indexed values of $\mathrm{P} / \mathrm{E}$ greater than 1 in the base year tended to decrease by the end of the period. Conversely, those that began with values less than 1 generally showed an increase, with about two-thirds of the state observations following that pattern. More formally, a cross-tabulation table can be constructed (Table 2) that compares the direction of change in the index with the index value in the base year. The null hypothesis in the $\chi^{2}$ test is cell independence, corresponding to no correlation between base values and direction of change over the three periods. Here, the calculated $\chi^{2}$ values strongly rejected the null hypotheses 
$(\mathrm{p}=.00034, .0035$, and .0012$)$, implying that relative market strength followed a relatively consistent process of convergence.

As expected, states in the Manufacturing Belt consistently show weak markets for all three years. All of the state indices $\left(\mathrm{MKT}_{\mathrm{i}}\right)$ in the region were less than 1, except for Maryland and West Virginia in 1990, but the index for every one of the 17 states also increased between the base year and 1990. Although almost every state increased in population, those increases were invariably below the national average, with the exception of New Hampshire. The region's market indices therefore tended to increase because employment changes (most decreased) were uniformly even farther below the national average than the population changes. These increases may reflect a decrease in overall comparative advantage or the shift of manufacturing employment to other regions, and the consistently low values are in keeping with the presence of significant regional exports or extensive backward linkages within manufacturing.

Analysis of individual states that deviated from the pattern of convergence is also instructive. Examining just the $1972-1990$ period, five states that had values greater than one in 1972, indicating stronger markets, actually showed increases in the index by 1990, contrary to the accepted hypothesis of convergence. Of these, Colorado and Oklahoma had negligible changes (and will be disregarded), while Florida, Louisiana, and Montana each experienced more significant change. What caused the relative market strength of these states to increase?

Florida's employment increased about 2.5 times faster than the national average over the period. This by itself would cause a region to appear to be oversupplied, but the index managed to increase because the rate of population growth was more than three times the national average. Florida has benefited from both foreign and domestic (im)migration, and supply has not grown as fast as demand. On the other hand, both Louisiana and Montana had modest population growth during the period (half the national average), but both states also lost a substantial amount of employment. In fact, they were two of only three states outside the Manufacturing Belt to suffer decreases in employment from 1954 to 1990.

What about the states that began with oversupplied markets? Table 4 shows that there were seven states having market indices less than one in 1972 that declined by 1990: Arkansas, Iowa, Kansas, Minnesota, Mississippi, Washington, and Wisconsin. For the index to decrease in a given period, employment must have increased faster than population, relative to their respective national averages. But one notable feature of these states is that, with the exception of Washington, they all are located in the central U.S., both north and south. An obvious hypothesis is that interior locations were gaining at the expense of places not quite as centrally located, perhaps because of transportation advantages (see discussion below). Washington stands alone in this group as the only state to have had strong population gains, but the index decreased because manufacturing employment in the state increased even faster than population. This could be attributed to a variety 
of factors, including distance from the Manufacturing Belt or proximity to markets in the Far East, but a more likely possibility is that almost 70,000 jobs were added in aircraft manufacturing due to the expansion of just one company, Boeing. Iowa, though it is an RTW state, had a below-average increase in manufacturing employment. By itself that should have increased $\mathrm{MKT}_{\mathrm{i}}$, but it declined because Iowa also had the largest population loss in the U.S.

The foregoing analysis suggests an underlying process whereby markets, as measured by the simple formulation $\mathrm{P} / \mathrm{E}$, eventually converge towards the national average. The hypothesis is further supported by the steadily declining variation in P/E for the three years; indeed, its coefficient of variation dropped from 12.1 in 1954 to 8.3 in 1990, indicative of $\sigma$-convergence (Eff 1999). In addition, a test for $\beta$-convergence over the entire period produced a highly significant $t$ statistic of -4.62; thus, the redistribution of manufacturing has resulted in less and less variation in market strength. If the underlying process of convergence were to continue, markets that were once oversupplied, such as the entire Manufacturing Belt, will eventually attain a better balance between employment and population, provided that population growth does not subside. The same is true of states that initially have undersupplied markets, as long as population does not grow too fast.

\section{DISCUSSION}

Regional studies of manufacturing have tended to focus on decentralization away from the core region brought about by a desire to exploit distant markets (West) or labor savings (South). But the results here suggest that the Manufacturing Belt's denouement of the last 50 years can be expected to subside as western $\mathrm{P} / \mathrm{E}$ ratios continue to decline and the Manufacturing Belt's continue to increase. Both southern and western markets are now more efficiently served by local producers than they were 50 years ago, and their degree of undersupply has decreased substantially. There is, however, little threat that declining labor costs in the West will allow producers to compete in markets back East; transport costs are simply too great. If anything, the results suggest that the residual hegemony of the Manufacturing Belt could be more seriously threatened by the Southeast or the central states. ${ }^{18}$

Although there seems to be little argument that markets and labor were the driving forces behind manufacturing location in the 20th century, it is obvious that estimates of future regional growth of manufacturing must take into account spatial variations in the composition of labor as well. Rigby's (1992) assertion that the Manufacturing Belt did not simply export assembly-type jobs to the Sunbelt may have some validity, but the increasing prevalence of production-line work in portions of the Sunbelt, notably the Southeast, should not be overlooked. By 1990, the Southeast was nearly 17 percent above the Manufacturing Belt in its percentage

${ }^{18}$ The hegemony of the Manufacturing Belt is much less than in the past, but by 1992 seven of the top 10 states in manufacturing employment were still located in the Manufacturing Belt, as defined here. The East North Central and the mid-Atlantic regions alone accounted for 36 percent of employment in manufacturing. 
of production workers-and increasing. The data only partially agrees with the findings of Moriarty (1992), however, who determined that, on average, the density of production workers increased with increasing distance from the core region. ${ }^{19}$ The Southwest portion of the Sunbelt, except for New Mexico, has not become the same magnet for production that the Southeast has; the relative concentration of production workers in Texas and California, for example, actually decreased from 1954 to 1990.

What, if anything, do the data suggest about the regional growth of manufacturing beyond the study period? Will the increasing attraction of assembly and production line work propel the Southeast to become the next manufacturing belt? Crandall's (1993) analysis would seemingly support that contention since he believes that unions will continue to push manufacturers away from the Northeast. Others, such as Mancur Olson (1983), disagree. They speculate that the South and West will soon "catch up" and adopt similarly counterproductive industrial policies, such as the removal of RTW laws that have always stimulated growth. But there are several other considerations arising from this, and other, studies:

(1) Not all manufacturing industries have a labor orientation, which we have seen is the primary comparative advantage of the Southeast. According to a typology developed by Latham (1978), only 17 percent of 199 four-digit industries in manufacturing were found to be labor oriented. And even if labor-cost savings were important to many more firms than predicted, such potential savings would steadily be eroded if wage and income levels in the South continue to rise.

(2) As mentioned above, markets located farther from the Manufacturing Belt, especially in the West, are becoming less undersupplied, while the Manufacturing Belt is becoming less oversupplied. This will eventually benefit the Manufacturing Belt and simultaneously reduce the growth prospects of other regions. Manufacturing's growth rate in the Southeast already slowed considerably during the study period, declining from 74.0 percent between 1954 and 1972 to 15.6 percent between 1972 and 1990.

(3) As noted by Hansen (1994), producer services can provide an important catalyst for regional development by enhancing productivity. According to Beeson and Husted (1989), productivity is affected by urbanization, high education levels, and moderately high capital-labor ratios, all characteristics of the old Manufacturing Belt. Kahn and Lim (1998), in addition, found strong evidence that productivity growth is increasingly concentrated in the more skill-intensive manufacturing industries. Therefore, the Manufacturing Belt's increase in nonproduction workers reflects (or creates) a comparative advantage in producer services and skill-intensive manufacturing, which will allow the region to maintain

${ }_{19}$ Moriarty (1992) used New York City as the center of the core region and developed production-worker density gradients based on distance from that central point. 
viability despite the efforts of firms to seek geographical diversification of their functional operations. ${ }^{20}$

(4) To the extent that the North specializes in knowledge-intensive, rather than labor-intensive, goods (Rigby and Essletzbichler 1997), it would be better positioned to exploit the international division of labor. Sachs and Shatz (1994) found that production jobs decreased about 3.5 times faster than nonproduction jobs after 1978 because of low-priced foreign imports. Regions like the Southeast will become more vulnerable to foreign competition if they continue to exploit the latter stages of the product cycle.

A second, more interesting, possibility is that states in the central U.S. may form a new manufacturing belt. Both market and labor considerations seem to support this scenario. If wage rates are in fact converging, then labor will become less of a discriminating location factor. And, if population continues its southern and western movement (at this time the median population center of the U.S. is approximately south central Missouri), industries serving national markets might prefer locations in the central U.S. to the extent that their desire is to minimize total transport costs.

Evidence for the beginnings of a redistribution of manufacturing to the central U.S. may be seen in Table 4. In particular, we may observe the shifts in market values $\left(\mathrm{MKT}_{\mathrm{i}}\right)$ for the 16 central states extending from North Dakota and Wisconsin in the North to Texas and Mississippi in the South (including Kentucky and Tennessee): by 1990, 10 of those states had values of $\mathrm{MKT}_{\mathrm{i}}$ less than .81 , and the value of $\mathrm{MKT}_{\mathrm{i}}$ decreased over the study period in 11 of the 16 states. This reflects the fact that their employment generally increased faster than their population over the period. By 1990, 14 of the 16 states either had a value that was less than 1 , or a value that had decreased since $1954 .{ }^{21}$ However, production-line manufacturing seems to have experienced the greatest growth in these states since (as shown in Table 3) the $\mathrm{PWP}_{\mathrm{i}}$ increased in 12 of the 16 states. Whether this region will eventually rival the Manufacturing Belt in terms of skill-biased technical change remains to be seen.

\section{SUMMARY AND CONCLUSION}

Regional labor rates, the spatial composition of labor, and the behavior of markets can lend useful insights into the regional growth of manufacturing. If nothing else, the overwhelming importance of markets and labor should be welcome news to those involved in the study of manufacturing location and growth, because labor and market data are so readily available. But in the case of markets $(\mathrm{P} / \mathrm{E})$, the researcher must tread carefully on a fragile set of assumptions, and the

\footnotetext{
${ }^{20}$ Rigby $(1992$, p. 418$)$ also points to these conclusions, claiming that "the productivity of nonproduction manufacturing workers has increased much more slowly in the sunbelt than in the snowbelt of the U.S."

${ }^{21}$ The only exceptions were Louisiana and Texas. But in Texas the value of $\mathrm{MKT}_{\mathrm{i}}$ increased (and was greater than 1 in 1990) because even though employment increased about 60 percent faster than the national average, the rate of population growth was twice the national average. Note also that the .81 level for $\mathrm{MKT}_{\mathrm{i}}$ is used here as an ad hoc benchmark since it was the average $\mathrm{MKT}_{\mathrm{i}}$ value for the Manufacturing Belt over the study period.
} 
results may be applicable only to the broadest of regions. Nevertheless, the convergence of markets is consistent with prior studies and reflects the eagerness of firms to capture the profits of market locations.

In the case of labor wage rates, the Manufacturing Belt stands out as the only region to deviate from the pattern of convergence. This highlights the importance of regional and state analysis, since overall measures ( $\sigma$ - and $\beta$-convergence, and $\chi^{2}$ tests for independence), all of which point to convergence, mask the fact of divergence in the Manufacturing Belt. ${ }^{22}$ But the latter trend is consistent with studies that have suggested for many years that the North's greater production wages and unionization provided a major, if not the major, impetus for some firms to head elsewhere. Many other firms closed altogether when they could not compete with newer facilities located in lower-wage regions such as the Southeast. The product cycle provides one rationale for this dynamic.

The new spatial composition of labor suggests that the Manufacturing Belt has experienced skill-biased technical change to a greater degree then other regions. The redistribution of unskilled labor, notably to the Southeast, follows directly from Goldfarb, Yezer, and Crewe's (1983) finding of greater regional wage differences for unskilled versus skilled labor, and from Oster (1979), who found that location search was more important in industries with a higher percentage of unskilled labor. Of course, regional technical change may be considered by some to be a peripheral issue compared to the larger phenomenon of Sunbelt resurgence and northern decline. But what the Manufacturing Belt has lost in numbers, it may have replaced with a capacity for innovation and new, cutting-edge technology. Florida's (1996) recent survey of manufacturers discovered a high rate of innovation in the Midwest, and Riefler (1995) found that eight of the top 15 states ranked by manufacturing competitiveness were in the Manufacturing Belt. The seedbed function of the Manufacturing Belt, often referred to by R.D. Norton $(1986,1992)$ and others, may indeed be alive and well.

Chinitz (1986) may have typecast regional growth of manufacturing best when he associated the West with "demand pull," the South with "cost-push," and the North with "resiliency." With markets in the West shrinking and labor rates converging, the resiliency of the North may prove to be the greatest resource of all. This echoes Rostow (1960), whose "stages of growth" model included a fifth stage characterized by a well-developed social, technical, or organizational infrastructure. Further growth is assured once regions manage to reach the fifth stage, since it allows them continually to find new exports to replace outmoded ones. The new international division of labor implies that regions trapped at the end of the product cycle (the Southeast?) may be the most vulnerable of all. On the other hand, if regions of the U.S. are in fact becoming more homogeneous, as suggested by both Chinitz (1986) and Bradshaw (1988), centralization may be the key to determining the location of the next manufacturing belt in the United States.

\footnotetext{
${ }^{22}$ Note that although this paper deals only with production wages, the results mirror those obtained for personal income by Crown and Wheat (1995), which is not surprising given Bernard and Jones' (1996) finding that manufacturing had the greatest impact on the growth in overall state labor productivity.
} 


\section{REFERENCES}

Barro, Robert H., and Xavier Sala-i-Martin. "Convergence." Journal of Political Economy 100 (2) (1992), 223-251.

Bartik, Timothy J. "The Effects of Environmental Regulation on Business Location in the United States." Growth and Change 19 (1988), 22-43.

Beeson, Patricia E., and Steven Husted. "Patterns and Determinants of Productive Efficiency in State Manufacturing." Journal of Regional Science 29 (1989), 15-28.

Beeson, Patricia E., and Randall W. Eberts. "Identifying Productivity and Amenity Effects in Interurban Wage Differentials." Review of Economics and Statistics 71 (1989), 443-452.

Berman, Eli, John Bound, and Zvi Griliches. "Changes in the Demand for Skilled Labor within U.S. Manufacturing: Evidence from the Annual Survey of Manufactures." The Quarterly Journal of Economics 109 (1994), 367-397.

Bernard, Andrew B., and Charles I. Jones. "Productivity and Convergence Across U.S. States and Industries." Empirical Economics 21 (1996), 113-135.

Blackley, Paul R. "Urban-Rural Variations in the Structure of Manufacturing Production." Urban Studies 23 (1986), 471-483.

Bradshaw, Michael. Regions and Regionalism in the United States. London: Macmillan Education, 1988.

Carlino, Gerald A., and Leonard Mills. "Testing Neoclassical Convergence in Regional Incomes and Earnings." Regional Science and Urban Economics 26 (1996), 565-590.

Carlino, Gerald A. and Richard Voith. "Accounting for Differences in Aggregate State Productivity." Regional Science and Urban Economics 22 (1992), 597-617.

Caves, Richard E., Matthew B. Krepps, M.J. White, and H. Farber. "Fat: The Displacement of Nonproduction Workers from U.S. Manufacturing Industries." Brookings Papers on Economic Activity Special Issue 2 (1993), 227-288. Chinitz, Benjamin. "The Regional Transformation of the American Economy." Urban Studies 23 (1986), 377-385.

Chinitz, Benjamin, and Raymond Vernon. "Changing Forces in Industrial Location." Harvard Business Review 38 (1960), 126-136.

Connaughton, John E., and Ronald A. Madsen. "The Changing Regional Structure of the U.S. Economy." Growth and Change 21 (1990), 48-60.

Craig, Paul G., R. Netzer, and Wilbur R. Thompson. "Comments on the Papers by Fuchs and Isard and Schooler." Journal of Regional Science 1 (1959), 35-42.

Crandall, Robert W. Manufacturing on the Move. Washington, D.C.: The Brookings Institution, 1993.

Crown, William H., and Leonard F. Wheat. "State Per Capita Income Convergence Since 1950: Sharecropping's Demise and Other Influences." Journal of Regional Science 35 (1995), 527-552.

de Bartolome, Charles A. M., and Mark M. Spiegel. "Does State Economic Development Spending Increase Manufacturing Employment?" Journal of Urban Economics 41 (1997), 153-175. 
Deller, Steven C., Martin Shields, and David Tomberlin. "Price Differentials and Trends in State Income Levels: A Research Note." The Review of Regional Studies 26 (1996), 99-113.

Duffy, Neal E. "The Determinants of State Manufacturing Growth Rates: A TwoDigit-Level Analysis." Journal of Regional Science 34 (1994), 137-162.

Eff, E. Anthon. "Myrdal contra Ohlin: Accounting for the Sources of U.S. County Per Capita Income Convergence Using a Flexible Decomposition Approach." The Review of Regional Studies 29 (1999), 13-36.

Florida, Richard. "Regional Creative Destruction: Production Organization, Globalization, and the Economic Transformation of the Midwest." Economic Geography 72 (1996), 314-334.

Fuchs, Victor. "Changes in the Location of Manufacturing Since 1929." Journal of Regional Science 1 (1959), 1-17.

Goldfarb, Robert S., Anthony M.J.Yezer, and Sebastian Crewe. "Have Regional Wage Differentials Really Disappeared?" Growth and Change 14 (1983), 48-51. Goldin, Claudia, and Lawrence F. Katz. "The Origins of Technology-Skill Complementarity." The Quarterly Journal of Economics 113 (1998), 693-732.

Hansen, Niles. "The Strategic Role of Producer Services in Regional Development." International Regional Science Review 16 (1994), 187-195.

"Regional Consequences of Structural Changes in the National and International Division of Labor." International Regional Science Review 11 (1988), 121-136.

Herzog, Henry W., Jr., and Alan M. Schlottmann. "Labor Force Mobility in the United States: Migration, Unemployment, and Remigration." International Regional Science Review 9 (1984), 43-58.

Kahn, James A., and Jong-Soo Lim. "Skilled Labor-Augmenting Technical Progress in U.S. Manufacturing." Federal Reserve Bank of New York Staff Reports 47 (1998).

Krugman, Paul. "History and Industry Location: The Case of the Manufacturing Belt." American Economic Association, Papers and Proceedings 81 (1991), 80-83. Latham, William R. III. "Measures of Locational Orientation for 199 Manufacturing Industries." Economic Geography 54 (1978), 53-65.

Lawrence, Robert Z., and Matthew J. Slaughter. "International Trade and American Wages in the 1980s: Giant Sucking Sound or Small Hiccup?" Brookings Papers on Economic Activity (1993), 161-210.

Levy, Frank. Dollars and Dreams: The Changing American Income Distribution. New York: W.W. Norton \& Company, 1988.

McLaughlin, Glenn E., and Stefan Robock. Why Industry Moves South. Washington, D.C.: National Planning Association, 1949.

Moriarty, Barry M. “The Manufacturing Employment Longitudinal Density Distribution in the USA." The Review of Regional Studies 22 (1992), 1-24. . "Hierarchies of Cities and the Spatial Filtering of Industrial Development." Papers of the Regional Science Association 53 (1983), 59-82. 
Myrdal, Gunnar. Economic Theory and Under-Developed Regions. London: G. Duckworth, 1957.

Nissan, Edward, and George Carter. "Income Inequality Across Regions Over Time." Growth and Change 24 (1993), 303-319.

Norton, R.D. "Industrial Policy and American Renewal." Journal of Economic Literature 24 (1986), 1-40.

"Agglomeration and Competitiveness: From Marshall to Chinitz." Urban Studies 29 (1992), 155-170.

Norton, R.D., and John Rees. "The Product Cycle and the Spatial Decentralization of American Manufacturing." Regional Studies 13 (1979), 141-151.

Ohlin, Bertil. Interregional and International Trade. Rev. ed. Cambridge: Harvard University Press, 1967.

Olson, Mancur. "The South Will Fall Again: The South as Leader and Laggard in Economic Growth." Presidential Address to the Southern Economic Association, Southern Economic Journal 49 (1983), 917-932.

Oster, Sharon. "Industrial Search for New Locations: An Empirical Analysis." Review of Economics and Statistics 61 (1979), 288-292.

Phillips, Keith R. "Regional Wage Divergence and National Wage Inequality." Federal Reserve Bank of Dallas Economic Review Fourth Quarter (1992), 31-43.

Riefler, Roger F. "Comparative State Employment Growth: an Exploratory Investigation." The Review of Regional Studies 25 (1995), 187-205.

Rigby, David L. "The Impact of Output and Productivity Changes on Manufacturing Employment." Growth and Change 23 (1992), 405-427.

Rigby, David L., and Jurgen Essletzbichler. "Evolution, Process Variety, and Regional Trajectories of Technological Change in U.S. Manufacturing." Economic Geography 73 (1997), 269-284.

Rostow, Walt W. The Stages of Economic Growth; a non-Communist Manifesto. Cambridge: Cambridge University Press, 1960.

Sachs, Jeffrey D., and Howard J. Shatz. "Trade and Jobs in U.S. Manufacturing." Brookings Papers on Economic Activity 1 (1994), 1-69.

Schmenner, Roger W. Making Business Location Decisions. Englewood Cliffs, N.J.: Prentice-Hall, 1982.

. The Manufacturing Location Decision: Evidence from Cincinnati and New England. Washington, D.C.: Economic Development Administration, 1978.

Vernon, Raymond. "International Investment and International Trade in the Product Cycle." Quarterly Journal of Economics 80 (1966), 190-207.

Wheat, Leonard F. "The Determinants of 1963-1977 Regional Manufacturing Growth: Why the South and West Grow." Journal of Regional Science 26 (1986), 635-659.

. Regional Growth and Industrial Location: An Empirical Viewpoint. Lexington, Mass.: D.C. Heath, 1973.

Williamson, Jeffrey G. "Regional Inequality and the Process of National Development: A Description of the Patterns." Economic Development and Cultural Change 13 (1965), 3-45. 